\title{
Professional Learning Communities in Malaysian Schools: A Contemporary Literature Review
}

\author{
Kamarudin Ismail $^{1, *}$, Rosnah Ishak ${ }^{1}$, Siti Hajar Kamaruddin ${ }^{2}$ \\ ${ }^{1}$ Faculty of Management and Economics, Universiti Pendidikan Sultan Idris, Malaysia \\ ${ }^{2}$ Faculty of Business, Economics and Social Development, Universiti Malaysia Terengganu, Malaysia
}

Received January 30, 2020; Revised March 19, 2020; Accepted March 28, 2020

Copyright $\odot 2020$ by authors, all rights reserved. Authors agree that this article remains permanently open access under the terms of the Creative Commons Attribution License 4.0 International License

\begin{abstract}
Most professional learning community or PLC studies were often conducted in the Western context. Hence, this literature review study aims to analyze PLC studies among primary and secondary schools in Malaysia between 2009 and 2018. The sources for the data collection process were obtained through searches on Google Scholar pages, Malaysian Citation Index (MyCite), and Scopus using the identified keywords, which are 'professional learning community', 'school', and 'Malaysia'. As a result, 35 empirical studies on PLC have been identified based on the set criteria through published journal articles and seminar papers. A scoping review through a narrative synthesis of the selected literatures, there are five main themes; PLC research methodology, PLC characteristics, PLC practices, the role of higher learning institution researchers, and PLC issues. There have been positive developments in PLC in terms of research and practice. However, the amount of local PLC studies is scarce compared to the Western context. A more robust empirical research is needed to implement PLCs in Malaysia.
\end{abstract}

Keywords Malaysia, School, Professional Learning Communities, Professional Development

\section{Introduction}

The professional learning community (PLC) is a professional development strategy implemented in most countries according to different contexts nowadays (Pang \& Wang, 2016). Empirical studies have shown that PLCs positively impacted teachers' professional development and school improvement (Harris et al., 2017). In addition, the structure of PLC as a platform for teachers' involvement in a professional dialogue improves their pedagogy of teaching, contributing to the increase of student achievement (Bakar \& Jamian, 2016). This indicates that PLC is capable of developing teachers' capacity and schools as a learning organization (Kools \& Stolls, 2016).

Furthermore, various PLC terms have been proposed by scholars because of its loose concept (Lomos, 2017). Little did a preliminary study of PLC among teachers in 1982 by dubbing it as cohesion (Lomos, 2017). Afterwards, Rosenholtz's study (1989) provided the term collaboration. Other than that, several terms came to surface such as professional community (Louis et al., 1996), learning community (McLaughlin \& Talbert, 2006), professional learning community/PLC (Hord, 1997), and professional learning network (Colwell \& Hutchison, 2018).

Although there are various terms, PLC remains as the umbrella concept that represents different types of community, for instance the learning community, learning community network, and community practitioners (Vangrieken et al., 2015). However, international scholars have agreed that PLC is a group of people who share and critically discuss on reflective teaching practices, collaboration, inclusiveness, and continuous improvement (Valckx et al., 2019). The five characteristics of PLC that form the community are the sharing of values and vision, collective responsibility, collaborative teachers, supported and shared leadership and supportive structure (Stoll \& Louis, 2007). These features have made the PLC model multidimensional due to its ability to gauge individual capacity, interpersonal capacity and organizational capacity (Sleegers et al., 2013).

Efforts to implement PLCs are actively being carried out by educators in most schools in Malaysia. The implementation of PLC in underperforming schools selected by the Ministry of Education started in 2011 (Ministry of Education, 2011). The initial PLC formation strategy was a lessons study. Furthermore, in 2012, the PLC strategy was diversified, and the number of schools being selected increases. Even the Malaysia Education Blueprint 2013-2025 launched by the Ministry of 
Education in 2013, has rendered PLC as one of its professional development strategies to improve the overall quality of teachers and education (Ministry of Education, 2014).

In line with the development of PLC implementations in Malaysia, more studies on PLC were carried out by local researchers. Similar efforts have been made by international researchers to find empirical evidence according to their locality as most of the literatures on PLC focuses more on Western context (Hairon \& 2012 Dimmock). This topic is significant because the implementation, form and functions of PLC vary according to the context of a country (Pang \& Wang, 2016). Thus, the question arises, what is the form and process of PLC implementations in Malaysia? Therefore, this contemporary literature review is done to provide an understanding of how PLC process is implemented in the context of Malaysia.

This study will analyze the literatures on PLC models and methodologies conducted by local researchers. In addition, this study will identify existing PLC issues and gaps for future studies. Based on local literatures, five main themes are highlighted below.

\section{Methodology}

The purpose of this literature review is to understand the scenario of PLC in Malaysia. This review uses a narrative synthesis approach (Gough, 2007). A narrative synthesis approach was chosen because it allows the reviewer to answer questions related to the topic being studied and integrate the findings (Gough, 2007). The process commences with filtering irrelevant articles, plot the findings, and synchronize the findings to a conclusion. Some aspects of the article have been identified such as the PLC research methodology used, the context of the study and their findings. Therefore, the article's search criteria are as shown in Table 1.

Table 1. The search criteria

\begin{tabular}{|l|l|}
\hline Content & Description \\
\hline Title & $\begin{array}{l}\text { Professional Learning Community in } \\
\text { Malaysia }\end{array}$ \\
\hline Date published & 2009 to 2018 \\
\hline Scope of study & Government's primary and secondary School \\
\hline Location of study & All states in Malaysia \\
\hline Publishing type & Journals, seminar papers \\
\hline
\end{tabular}

According to Table 1, the span of years set during article search was from 2009 to 2018 . The main objective of this time limit was chosen to obtain the latest published PLC articles in Malaysia over the last decade.

The review process involves several steps. The first step is to find articles containing the topic of professional learning community in Malaysia through search engines such as Google Scholar, Malaysian Citation Index (MyCite), and Scopus. The keywords used are; 'Komuniti
Pembelajaran Profesional' AND Malaysia; 'Komuniti Pembelajaran Profesional' AND sekolah; 'Professional Learning Communities' $A N D$ Malaysia; 'Professional Community' $A N D$ Malaysia. The initial search through Scopus and Malaysian Citation Index (MyCite) search engines have resulted in few numbers of articles to be analyzed. Therefore, the researchers further their search through another search engine, the Google Scholar. There were more articles, but they needed to be filter thoroughly.

Consequently, this review focused on studies conducted in primary and secondary schools. Therefore, PLC studies encompassing higher learning institutions and other than educational organizations were excluded because they were beyond the scope of this paper. PLC articles that were published in newspapers, blogs, websites and theses were also excluded. PLC sources from these were excluded as local articles are the result of or part of the theses findings. Thus, only articles published in journals and seminar papers that contain empirical evidence were all selected for the narrative analysis.

Thereafter, all selected articles were read carefully. Information on the articles' author names, titles, date published, objective of study, methodology, and findings were recorded systematically in Excel worksheet. Then, the synchronized findings were discussed in the next section.

\section{Results and Discussions}

This section discusses the findings resulted from review of local PLC researches. At the beginning of the PLC search through search engines, 160 articles were generated. However, after each article was assessed, only 35 articles (18 in Malay and 17 in English) met the criteria set by the reviewers. Based on the review analysis, there are five main themes; PLC research methodology, PLC characteristics, PLC practice, the role of higher learning institution researchers, and PLC issues.

\subsection{PLC Research Methodology}

Based on the 35 reviewed articles, the average publication for a period of 10 years is 3.5 articles a year. The number of articles published each year is shown in Figure 1.

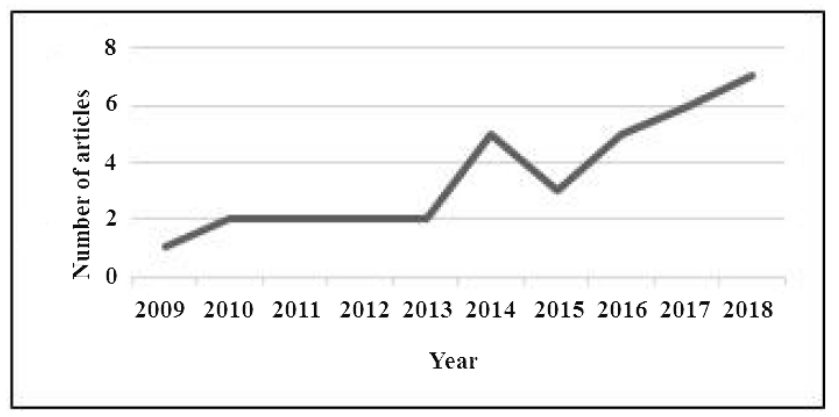

Figure 1. The number of published PLC articles in Malaysia (2009-2018) 
According to Figure 1, the number of published articles has escalated from 2009 to 2018. The increment reflects the ongoing interest of local researchers regarding PLC implementation in schools. Overall, 31 articles came from local studies while the other four articles were written by international researchers.

The PLC methods of investigation have various approaches; some studies are quantitative, qualitative or mixed in nature. Most quantitative research method has adapted models and instruments from the West to identify the dimensions of PLC and the level of PLC practices implementation in schools (e.g. Abdullah \& Ahmad, 2009; Mohamad et al., 2015). However, Ismail et al.'s (2018) study has adapted their PLC instrument to focus on Malay teaching subjects built by local expertise through Delphi technique. In the case of qualitative studies, most of them explored the process of implementing PLCs. Studies that applied mixed methods used the qualitative approach to support the findings from their quantitative procedure. Based on Figure 2, the methodologies used in PLC studies were $15(42 \%)$ quantitative, $16(46 \%)$ qualitative, and 4 (11\%) mixed methods. The data collection procedures for qualitative PLC studies included interviews, observations, and document analyses whereas quantitative studies used survey technique. Meanwhile, PLC studies that used a mixed method approach have combined both methodologies by conducting surveys, interviews, and experiments.

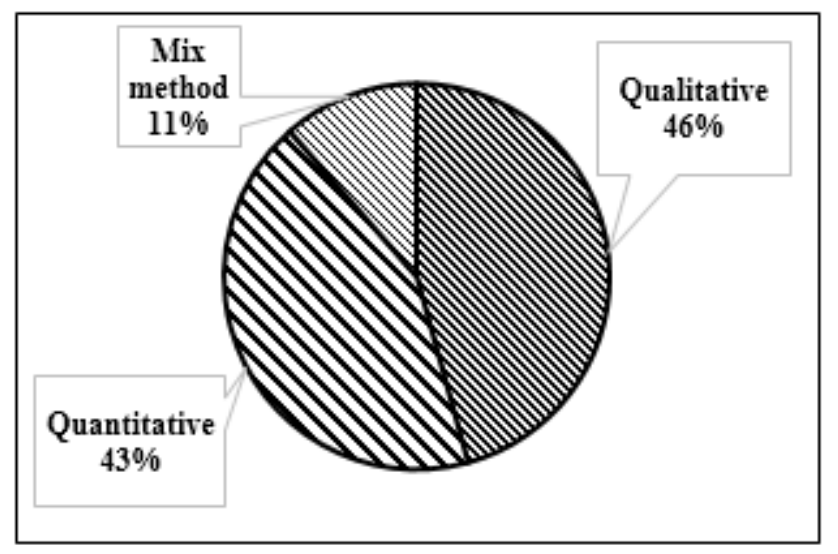

Figure 2. PLC research methodology

\subsection{PLC Characteristics}

According to the reviews of PLC articles, there are two types of PLC; school-based PLC ( $\mathrm{n}=28: 78 \%$ ), and online-based PLC $(\mathrm{n}=7: 20 \%)$. School-based PLC involves formal or informal teacher learning activities (McLaughlin \& Talbert, 2006). Teacher learning activities include teaching studies, action studies, peer-coaching, learning walks, and teaching supervision. Meanwhile, online-based PLC focuses more on professional job discussions online.

Studies have shown that the local school-based PLC characteristics were similar to Western PLCs. For example, Abdullah et al. (2012) have identified PLC characteristics in 50 secondary schools in Malaysia (i.e. leadership sharing and leadership support, sharing of values, goals, mission and vision, collective learning and applications, personal sharing practices and supportive situations). They have also identified the stages of the PLC implementation based on the initial stage, intermediate stage, and the practice stage. The schools that were identified to have every effective and continuous PLC characteristic are categorized into the practice stage.

In addition, several other PLC characteristics include focus on student learning, collaborative culture, decision-making, and reflective dialogue. Although the PLC implementation policy was only launched by the government in 2011, the philosophy behind PLC characteristics were found to have existed in the launch of Action Research Module in 1995 (Ministry of Education, 2008) for teachers to apply during their action research. Through the project, teachers were able to solve problems that arise from daily practices by reflecting individually or as a team to improve teaching practices and enhance their students' performance.

As for online-based PLCs, the practices include collaborative learning using online technology such as the internet and social media (Trust et al., 2016). In line with Western literatures, the theory of community practice is commonly found in online-based PLC studies (Feger \& Arruda, 2008). This form of learning community leans more towards the informal side and is built on the teachers' own initiative in Malaysia. Among the examples of online-based PLC studies are through ITC online community (Khalid, 2011), Facebook (Khalid et al., 2013), and blogs (Murugaiah et al., 2010; Nambiar et al., 2011). Their studies comply with the characteristics of PLC based on practitioner community's theory of mutual engagement, joint enterprise, and shared repertoire that are capable of enhancing teachers' professional development (Nambiar et al., 2011).

In addition, several other PLC structure studies related to leadership (Ibrahim \& Abdullah, 2014), teachers' self-efficacy (Ismail et al., 2015), Malay teaching subjects (Abdullah et al., 2018), English teaching subjects (Roselan, 2018; Ansawi \& Pang, 2017), teachers' competency (Rusdin \& Ambutton, 2018; Bakar \& Jamian, 2016; Thani $\&$ Othman, 2017), teachers' readiness level (Khusaini, 2018; Mazlan \& Mahamod, 2016), teachers based on specific subjects (Ngau \& Mansor, 2017), school culture (Yaakob \& Yunus, 2016) and learning walks strategy (Ahmad et al., 2018).

\subsection{PLC Practices}

In general, PLC practice studies include schools located in Peninsular Malaysia and the Borneo (i.e. Sabah and Sarawak). The types of school included are national 
primary school, Chinese national school, high-performing national school, secondary school, high-performing secondary school, national religious high school, full boarding secondary school, transformation school, and trustee school. Most studies measure the level of PLC practice in schools using different scale instruments. The majority of findings from quantitative studies have indicated that the level of PLC practice in school is high.

However, the levels of practice between schools were found to be different according to the type of school, band or school performance, and location (Wang et al., 2017). For example, Ismail et al. (2018) found that the practice level of each dimension differs between trustee school, transformation school, and high prestige school. In comparing between high and low prestige schools, the level of PLC practice in high prestige schools is higher than the lower ones (Ismail et al., 2014). In fact, Chong et al.'s (2017) study of SJKC high prestige school in Sarawak revealed a high level of PLC practice.

In terms of location, the level of PLC practice in schools situated in rural areas was only moderate (Aripin \& Hamzah, 2017). The difference in the level of PLC practice between school locations may be due to the lack of school structures that supported PLC (Ansawi \& Pang, 2017). In addition, the size of a PLC group in school may influence the level of PLC practice. A study by Chuan et al. (2013) found that the ideal size for a PLC group formation is around four to six people.

The practice of PLCs in Malaysian education system is currently considered to be top-down. However, the Ministry of Education Malaysia strives to transform the structure of PLC practices bottom-up by making it one of the proclaimed self-professional developments, which gives autonomy to school administrators and schoolteachers to implement it in schools.

\subsection{The Role of Higher Learning Institution Researchers}

Studies have found that higher learning institution researchers play a role in supporting the formation of PLC among schoolteachers (Hord \& Tobia, 2012). For example, a group of lecturers used teaching study strategies involving instructors and schoolteachers to assist them in forming PLC in school (Iksan et al., 2014). The result of that PLC formation had a positive impact on the teaching and learning process of teachers. In addition, efforts to improve PLCs using the developmental instructional supervision approach was carried out by Abdullah et al. (2016) to improve the quality of Malay subject. Furthermore, lecturers from teaching institutes have helped to promote the implementation of PLC in schools, especially using teaching study strategy as practice that can enhance the quality of teaching and learning (Chuan et al., 2013).

Correspondingly, online-based PLCs became the focus for university researchers to propagate PLC. This online-based collaboration of online teacher learning is informal and structurally bottom-up (Khalid et al., 2013). The efforts to explore professional development online were executed by university researchers such as Murugaiah et al. (2010) and Thang et al. (2010). They found that the involvement of teachers within the community added value to the improvement of their teaching skills and to enhance their competencies. However, the extent of how effective online-based PLCs can be as a strategy for the development of teachers' professionalism in Malaysia is unclear. This practice as a strategy is still indistinct because empirical studies on online-based PLCs are minimal compared to school-based PLCs.

\subsection{PLC Issues}

Several factors were identified during the review to prevent the formation of PLC implementation. The factors that can contribute or hinder the success of a PLC formation as stated by Sargent and Hannum (2009) are institutions in the education system, leadership characteristics, and the teachers themselves.

The first factor is the institution in the education system; referring to the school structure. A school's structure includes the time and space allocated for teachers to collaborate, workloads, and contextual factors (Thang et al., 2010). Studies by Thang et al. (2010), Rahim et al. (2015), and David et al. (2014) have proved that time is one of the main obstacles to forming PLCs in school. Workloads equally affect the implementation of PLCs in school. In fact, workload is a factor that is consistently found in PLC studies such as Rahim et al. (2015), Abdullah et al. (2016), Yaakob et al. (2017), Saad et al. (2017), and Chong et al. (2018).

Subsequently, the issue of high job pressure caused by certain policies has been discussed by international scholars such as Harris and Jones (2018). They believed that a strategy that is adapted from abroad should consider the local context and cultural background. This issue should be considered because PLC is the basis of training adapted from overseas (Mohamad et al., 2015). If the implementation of PLC does not meet the requirement of a local context, it may have an unexpected impact on the country's education system.

The second critical factor is leadership in PLC. Some studies have found the lack of competence among school leaders in implementing PLC in school. For example, Chong et al. (2018) found several leadership characteristics that prevented the practice of PLC in schools such as being less open-minded, less innovative, and autocratic. In addition, Mohamad et al. (2015) recommended that the Ministry of Education Malaysia improve the knowledge of school leaders as they were found to be less competent in starting PLCs in school.

The third factor is identified to be the teacher's own 
attitude. Abdullah et al. (2016) found that the teacher's attitude prevents the implementation of PLC. This factor is likely caused by the teacher's lack of understanding of PLC concept, which then hinders the process of PLC implementation. Teachers were also said to be embarrassed to be perceived by others (Mazlan \& Mahamod, 2016). In addition, the lack of motivation has caused teachers to feel weak and lack a sense of belonging during school (Chong et al., 2018). The sense of belonging or cohesion between teachers is an important trait for a PLC to operate effectively (Stoll \& Louis, 2007). Cohesion enables teachers to discuss openly in order to improve or enhance teaching practices in their classroom.

Another known factor to hinder the implementation of PLC in schools is the culture of that particular community. Scholars have been debating about cultures in their studies as there are differences between the western and eastern cultures. For example, the sharing of teaching practices in the West is carried out publicly and is widely available to colleagues regardless of age and work experience. However, Khalid et al. (2014) found that teachers did not fully share their practices with the community because they are afraid that their knowledge and skills are being perceived as condescending. Murugaiah et al. (2012) similarly found the same issue, which shows that modest cultures exist among teachers. The study also found that older and experienced teachers tend to have high dignity and confidence.

As a result, senior teachers cannot accept negative comments or feedbacks from younger and less experienced teachers. They perceived that younger teachers should respect them; thus, it is clear that a hierarchy exists within the teachers' community (Zawawi, 2008; Abdullah et al., 2016). Zawawi (2008) also described that the Malay community uses a 'sugar-coated' language while socializing with others. In most situations, it is considered inappropriate to be straightforward. Therefore, this condition is contrary to the Western communities. This cultural barrier has been debated by researchers from China, plus, it was one of the characteristics published in the PLC conceptual model developed by Zhang and Sun (2018).

\section{Conclusions}

This review of literature on PLCs in Malaysian secondary and primary schools in Malaysia gives an overview of PLC within the local context. Although the implementation of PLCs in Malaysia is relatively new, the Ministry of Education Malaysia has been implementing it as one of the reformation strategies for professional development in the Malaysia Education Blueprint (PPPM) 2013-2025, which positively influences the progress of PLC in terms of research and practice. However, this review has its limitations. The time span of the included articles was limited between 2009 to 2018 and possibly not all empirical studies on PLC in Malaysia can be detected by the reviewers. In addition, some methodological aspects in the included articles were not explicitly stated and thus resulting in information shortage to describe the study in depth.

Therefore, two recommendations are proposed so future research can be done. First, researchers should conduct more PLC studies because this topic has not been fully explored locally from various perspectives compared to Western studies. A more robust investigation is needed to enhance PLC practices in Malaysia. Secondly, the identified characteristics of PLC were widely adapted from the Western PLC model, which stirred some issues. For that reason, it is recommended that a new PLC model and instrument be developed by local researchers in accordance with the local context to serve as a guide for PLC implementation in schools. In conclusion, the concept of PLC must first be understood and practiced in order to become a professional development strategy and an effective school improvement practice.

\section{REFERENCES ${ }^{1}$}

[1] Abdullah, N.A.E., Mahamod, Z., \& Abdullah, N.A. (2018). Kajian pengajaran sebagai program pembangunan profesionalisme berterusan melalui komuniti pembelajaran profesional. International Journal of Education, Pyschology and Counselling, 3(14), 87-99.

[2] Abdullah, Z., \& Ahmad, A. (2009). Komuniti Pembelajaran Profesional: Satu kajian perbandingan antara sekolah menengah kebangsaan harian biasa dan sekolah menengah kebangsaan Anugerah Cemerlang 2007. Jurnal Administrasi Pendidikan, 10(2), 10-22.

[3] Abdullah, Z., Ahmad, R., Ghani, M.F.A., \& Salamun, H. (2012, Oktober). Komuniti pembelajaran profesional dalam kalangan warga sekolah menengah di Malaysia. Proceedings of the National Public Universities Dean Committe Conference. http://www.fp.utm.my/ePusatSumb er/listseminar/medc2012/pdf/117.pdf.

[4] Abdullah, Z., Manaf, Z.A., Ail, N.M.M., \& Ramzy, M.I. (2016). Pemerkasaan guru Bahasa Melayu melalui penyeliaan kembang tumbuh dan komuniti pembelajaran profesional (KPP) di lima sekolah menengah daerah Kuala Lipis. Jurnal Kepimpinan Pendidikan, 3(2), 42-59.

[5] Ahmad, J., Mohtar, H., \& Kamidin, T. (2018, Oktober) "Happy, loving, trust" dalam meningkatkan amalan pedagogi guru dan kemenjadian pelajar di Sekolah Menengah Kerajaan Hajjah Laila Taib. Proceedings of the International Conference on Education Transformation. 444-466.

[6] Ansawi, B., \& Pang, V. (2017). The Relationship between professional learning community and lesson study: A case study in low performing schools in Sabah, Malaysia. Sains Humanika, 9(1-3), 63-70.

${ }^{1}$ References marked with an asterisk indicate studies enclosed within the review. 
[7] Aripin, M.Z.A.Z., \& Hamzah, M.I. (2017, Mac) Pelaksanaan amalan komuniti pembelajaran profesional dalam meningkatkan keyakinan guru pedalaman mengajar. Proceedings of the Research Methodology in Education Conference. 230-244.

[8] Bakar, D.M.S.A.A., \& Jamian, A.R. (2016). Pelaksanaan komuniti pembelajaran profesional untuk peningkatan kemahiran guru Bahasa Melayu mengajar penulisan karangan. Jurnal Kurikulum dan Pengajaran Asia Pasifik, 4(3), 1-10.

[9] Chong, C. K., Ghani, M.F.A., \& Abdullah, Z. (2017). Amalan komuniti pembelajaran profesional (KPP) di sekolah berprestasi tinggi (SBT) Malaysia: Sebuah Sekolah Jenis Kebangsaan Cina (SJKC) di Sarawak. Jurnal Kepimpinan Pendidikan, 3(1), 43-70.

[10] Chong, C. K., Ghani, M.F.A., \& Abdullah, Z. (2018). Cabaran amalan komuniti pembelajaran profesional (KPP) dalam kalangan guru sekolah rendah berprestasi tinggi Malaysia. JuKu: Jurnal Kurikulum \& Pengajaran Asia Pasifik, 6(3), 1-14.

[11] Chuan, N. K., Jarrett, B., Smith, M., Taylor, W., Kwong, J., Noralidin, N., ... \& Ong, H. (2013). Professional learning communities across a Malaysian primary school (1-26). Asian Education Action Research Journal, 2(1), 1-26.

[12] Colwell, J., \& Hutchison, A.C. (2018). Considering a twitter-based professional learning network in literacy education. Literacy research and instruction, 57(1), 5-25.

[13] Daud, M.Y., Iksan, Z., Khalid, F., \& Rosli, R. (2014, November). Refleksi pendekatan lesson study dalam menjalani latihan mengajar oleh bakal guru sains di beberapa sekolah terpilih. Proceedings of the World Association of Lesson Studies International Conference. https://www.academia.edu/12919809/Refleksi_Pendekatan Lesson_Study_Dalam_Menjalani_Latihan_Mengajar_ole h_Bakal_Guru_Sains_Di_Beberapa__Sekolah_Terpilih

[14] Feger, S., \& Arruda, E. (2008). Professional learning communities: Key themes from the literature. Providence, RI: Education Alliance, Brown University.

[15] Gough, D. (2007). Weight of evidence: a framework for the appraisal of the quality and relevance of evidence. Research Papers in Education, 22(2), 213-228.

[16] Hairon, S., \& Dimmock, C. (2012). Singapore schools and professional learning communities: Teacher professional development and school leadership in an Asian hierarchical system. Educational Review, 64(4), 405-424.

[17] Harris, A., \& Jones, M. (2018). Why context matters: a comparative perspective on education reform and policy implementation. Educational Research for Policy and Practice, 17(3), 195-207.

[18] Harris, A., Jones, M., \& Huffman, J. B. (2017). Teachers leading educational reform: The power of professional learning communities. London: Routledge.

[19] Hord, S. M. (1997). Professional learning communities: Communities of continuous inquiry and improvement. Office of Educational Research and Improvement, 40(1), $58-59$.

[20] Hord, S. M., \& Tobia, E. F. (2012). Reclaiming our teaching profession: The power of educators learning in community. New York: Teachers College Press.

[21] Ibrahim, S., \& Abdullah, Z. (2014). Sokongan pengetua dalam amalan komuniti pembelajaran profesional di sebuah sekolah di Johor, Malaysia. Jurnal Peradaban, 7(1), 1-39.

[22] Iksan, Z. H., Rosli, R., Daud, M. Y., \& Khalid, F. (2014, November). Building learning community through lesson study approach during practical teaching. Proceedings of the World Association of Lesson Studies International Conference. https://www.academia.edu/12919825/Buildin g_Learning_Community_Through_Lesson_Study_Approa ch_During_Practical_Teaching

[23] Ismail, A., Baharom, N., \& Abdullah, A. G. K. (2014). Professional learning community practices in high and low performing schools in Malaysia. International Journal of Current Research and Academic Review, 2(9), 159-164.

[24] Ismail, A., Loh, H.L., \& Abdullah, A.G.K. (2015). Komuniti pembelajaran profesional dan efikasi kendiri guru sekolah menengah Pulau Pinang. Jurnal Kepimpinan Pendidikan, 2(1), 1-12.

[25] Ismail, S.N., Abdullah, Z., Othman, A.J., \& Shafie, S. (2018). Amalan komuniti pembelajaran profesional dalam kalangan guru Bahasa Melayu di Selangor. Jurnal Kepimpinan Pendidikan, 5(4), 1-19.

[26] Khalid, F. (2011, Mac). Elements of a successful online community of practice: An investigation of the information technology coordinators (ITCs) group. Proceesings of the Global Learn Asia Pacific- Global Conference on Learning and Technology. 1153-1161.

[27] Khalid, F., Joyes, G., Ellison, L., \& Daud, M. Y. (2014). Factors influencing teachers' level of participation in online communities. International Education Studies, 7(13), 23-32.

[28] Khalid, F., Joyes, G., Ellison, L., \& Karim, A. (2013). Teachers' involvement in communities of practice: An implication with regard to the current approach of teachers' professional development in Malaysia. Asian Social Science, 9(16), 102-111.

[29] Khusaini, E.A. (2018). Tahap kesediaan guru cemerlang Bahasa Melayu terhadap perlaksanaan komuniti pembelajaran profesional di sekolah menengah di negeri Melaka. Jurnal Pendidikan Bahasa Melayu, 8(1), 63-73.

[30] Kools, M., \& Stoll, L. (2016). What makes a school a learning organization?. Paris: OECD Publishing.

[31] Lomos, C. (2017). To what extent do teachers in European countries differ in their professional community practices? School Effectiveness and School Improvement, 28(2), 276291.

[32] Louis, K. S., Marks, H. M., \& Kruse, S. (1996). Teachers' professional community in restructuring schools. American Educational Research Journal, 33(4), 757-798.

[33] Mazlan, R., \& Mahamod, Z. (2016). Faktor-Faktor yang mempengaruhi kesediaan guru Bahasa Melayu melaksanakan kajian pengajaran. Jurnal Pendidikan Malaysia 41(2), 173-182.

[34] McLaughlin, M. W., \& Talbert, J. E. (2006). Building school-based teacher learning communities: Professional 
strategies to improve student achievement. New York: Teachers College Press.

[35] Ministry of Education. (2008). Manual Kajian Tindakan. Putrajaya: Kementerian Pendidikan Malaysia.

[36] Ministry of Education. (2011). Komuniti Pembelajaran Profesional, Strategi 2: Amalan Penswastaan (De-privatization of Practise). Kuala Lumpur: Percetakan Nasional Malaysia Berhad.

[37] Ministry of Education. (2014). Pelan Pembangunan Profesionalisme Berterusan (Guru dan Pemimpin Sekolah) Edisi 2014, Putrajaya: Kementerian Pendidikan Malaysia.

[38] Mohamad, A. M., Azhar, Z.N., Muhammad, A., \& Embong, W.H.W. (2015). Komuniti pembelajaran profesional: Aplikasi dalam kalangan komuniti SMKA di negeri Johor. International Journal of Islamic Studies and Arabic Language Education, 2(1), 11-22.

[39] Murugaiah, P., Azman, H., Thang, S. M., \& Krish, P. (2012). Teacher learning via communities of practice: A Malaysian case study. International Journal of Pedagogies and Learning, 7(2), 162-174.

[40] Murugaiah, P., Azman, H., Ya'acob, A., \& Thang, S. (2010). Blogging in teacher professional development: Its role in building computer-assisted language teaching skills. International Journal of Education and Development using ICT, 6(3), 73-87.

[41] Nambiar, R., Wah, L. K., Khalid, F., Ming, T. S., \& Krish, P. (2011). Blogging to build a community of practice (CoP): Malaysian mathematic teachers' involvement and participation in online teacher professional development. Journal of Institutional Research South East Asia, 9(2), 6-20.

[42] Ngau, C., \& Mansor. A.Z. (2017, Mac). Persepsi dan amalan komuniti pembelajaran profesional dalam kalangan guru Matematik di daerah Bau. Proceedings of the Research Methodology in Education Conference. 90-99.

[43] Pang, N. S. K., \& Wang, T. (2016). Professional learning communities: research and practices across six educational systems in the Asia-Pacific region. Asia Pacific Journal of Education, 36(2), 193-201.

[44] Rahim, S.S.A., Sulaiman, S., \& Sulaiman, T. (2015). Teacher professional development through lesson study in secondary schools. Advanced Science Letters, 21(7), 2360-2364.

[45] Roselan, F.I. (2018). Effectiveness of lesson study in the teaching of lower primary English as a Second Language (ESL) class. International Research Journal of Education and Sciences, 2(1), 7-12.

[46] Rusdin, R., \& Ambutang, A.S. (2018). The role of the implementation of the professional learning community on the competence of science teacher in Sabah. International Journal of education, psychology and Counselling, 3(14), 22-30.

[47] Saad, K.A., Walsh, B.A., Mallaburn, A., \& Brundrett, M. (2017). Exploring the implementation of a professional learning communities in Malaysian's schools. International Journal of Education, Psychology and Counselling, 2(5), $1-18$.
[48] Sargent, T. C., \& Hannum, E. (2009). Doing more with less: Teacher professional learning communities in resource-constrained primary schools in rural China. Journal of Teacher Education, 60(3), 258-276.

[49] Sleegers, P., den Brok, P., Verbiest, E., Moolenaar, N. M., \& Daly, A. J. (2013). Toward conceptual clarity: A multidimensional, multilevel model of professional learning communities in Dutch elementary schools. The Elementary School Journal, 114(1), 118-137.

[50] Stoll, L., \& Louis, K. S. (2007). Professional learning communities: Divergence, Depth and Dilemmas. New York: Open University Press.

[51] Thang, S. M., Murugaiah, P., Lee, K. W., Azman, H., Tan, L. Y., \& Lee, Y. S. (2010). Grappling with technology: A case of supporting Malaysian smart school teachers' professional development. Australasian Journal of Educational Technology, 26(3), 400-416.

[52] Thani, R.A., \& Othman, N.H. (2017, Mac). Lesson study dan pengajaran guru. Proceedings of the Research in Education Conference. 340.349.

[53] Trust, T., Krutka, D.G., \& Carpenter, J.P. (2016). "Together we are better": Professional learning networks for teachers. Computers \& education, 102(1), 15-34.

[54] Valckx, J., Vanderlinde, R., \& Devos, G. (2019). Departmental PLCs in secondary schools: the importance of transformational leadership, teacher autonomy, and teachers' self-efficacy. Educational Studies, 1-20, doi:10.1080/0305 5698.2019.1584851

[55] Vangrieken, K., Dochy, F., Raes, E., \& Kyndt, E. (2015). Teacher collaboration: A systematic review. Educational research review, 15(1), 17-40.

[56] Wang, D., Wang, J., Li, H., \& Li, L. (2017). School context and instructional capacity: A comparative study of professional learning communities in rural and urban schools in China. International Journal of Educational Development, 52(1), 1-9.

[57] Yaakob, M.F.M., \& Yunus, N. (2016). The Relationship between school culture and professional learning community in Malaysia. International Journal of Academic Research in Business and Social Sciences, 6(12), 231-236.

[58] Yaakob, M.F.M., Hasbullah, H., Yunus, J.N., \& Yusuf, H. (2017). Modelling professional learning community among Malaysian teachers. Man In India, 97(24-II), 277-290.

[59] Zawawi, D. (2008). Cultural dimensions among Malaysian employees. International Journal of Economics and Management, 2(2), 409-426.

[60] Zhang, J., \& Sun, Y. (2018). Development of a conceptual model for understanding professional learning communities in China: a mixed-method study. Asia Pacific Education Review, 19(4), 445-457. 